\title{
PRESUPPOSITION AND IDEOLOGY: A CRITICAL DISCOURSE ANALYSIS OF JOE BIDEN'S INAUGURAL SPEECH
}

\author{
Zainal Arifin Renaldo ${ }^{1}$ \\ ${ }^{1}$ Politeknik Caltex Riau \\ ${ }^{1}$ zainal@pcr.ac.id
}

\begin{abstract}
The 2020 U.S presidential election came with the result of Joe Biden's victory. This research is aimed at investigating Biden's ideology manifested in his inaugural speech which was delivered on January 20, 2021. The analysis in this research was conducted under the theory of Critical Discourse Analysis (CDA). In finding the ideology, the researcher worked on the microstructure level by studying the presupposition as proposed by Dijk. The result of this research shows that there are three types of presupposition present in Biden's inaugural speech i.e. lexical, existential, and factive in which lexical presupposition appear to be the most frequent one. The analysis of the presupposition also result to the finding of Biden's ideology manifestation towards the issue of immigrants, healthcare, racism, democracy, and climate change.
\end{abstract}

Keywords: Presupposition, Ideology, Inaugural Speech

\section{INTRODUCTION}

Long before the modern era, humans have been known to be involved in political activities as it is an inseparable part of their life. The idea of men being political had been introduced by Plato in the Phaedo as he used the term "political animal". This idea was later widely elaborated by Aristotle as he stated that man is a political animal by nature. Politics itself is closely related to the action of making influence towards others which in this case, society. The use of power is considered inevitable in influencing others in order to make them do what is being told to. Power is a force that facilitates someone to perform an action such as ruling other people, controlling natural resources, or investing an idea to someone else. As Edelman (1977) postulated in Ideology and Political Discourse: A Critical Discourse Analysis Of Erdogan's Political Speech, the power-holder is a person who can exercise influence outside the context of formal proceedings (Bayram, 2010). From this, it can be drawn that order to be able to control others, someone has to be influential so that the power can be applied to other people.

Speaking of politics, one element that cannot be simply ignored is political discourse. The attention on political discourse has been widely developed under different point of views. It has been discussed by different discipline and different theories. This fact shows that political activities in which political discourse is integrated is considered to be one of the anticipated issues among worldwide societies. The nature of human beings who cannot separate their life with others lead us to the fact that we will surround ourselves with politics be it internally or externally.

The cooperation between language and politics is viewed as a mutual partnership. It has been considered to be integrated element in political activities. What is being said by someone might 
have an affective function to others. The force that is carried by language serves as an important in which it is called as power. Fairclough (2020) stated that power in language is to do with powerful participants controlling and constraining the contributions of non-powerful participants. This force is what enables someone in political activities to assert their knowledge, power, or ideology. Dijk (2006) stated that political situation do not simply cause political actors to speak in certain ways, instead, there is a need for a cognitive collaboration between situation and text that is context which defines how participants experience, interpret, and represent the relevant aspect of political situation. This is again emphasizing that the language used in political discourse definitely plays substantial role to assert power among others. The fact that language can be used to persuade represents how language becomes a vital element in politics.

One vital element in political discourse is the manifestation of ideology. For an ideology to be able to reproduce, it needs to be transferred. In transferring the ideology, one system that can be utilized is the use of language. By asserting ideology through speech, the cycle of ideology is possible to continue. Ideology is a system (with its own logic and its own rigor) of representations (images, myths, ideas or concepts), possessing an existence and a historical role within a given society. The act of transferring an ideology has been done in the early years of modern life. It serves a function to reproduce the means of production and ensuring the dominance continuity of the ruling class.

The 2020 U.S. presidential election became one of the most anticipated events not only in the states but also worldwide. This is due to the fact that U.S internal and foreign affairs for the past four years under the administration of Donald Trump had affected many parties in the world. His policy on racial issues, terrorism, even the most current grand problem faced by the world, Covid-19, was considered unusual and led to various responses. Trump's peculiar way of ruling, in fact, shook the political climate not only inside but also outside. Many of his foreign affairs policy were considered unpopular as they triggered uncomfortable response by other countries. The 2020 U.S presidential election came with the result that Joe Biden to win this hot seat. Although there were some conflict occurred prior to his inauguration, Joe Biden managed to proceed to vacant the most powerful position in this superpower country. In his inauguration, similar to his predecessors, Biden delivered a speech to mark his official status as the President of The United States. His speech becomes an interesting object to be studied especially by Critical Discourse Analysis.

This research investigates the types of presupposition in Biden's inaugural speech. The speech transcript is taken from The White House official website www.whitehouse.gov. Descriptive qualitative analysis is used to classify the type of presupposition. The analytical part of this research lies on the extraction of ideology from the meaning obtained in the speeches through presupposition. The ideology of Biden is later elaborated into several classification. This research serves a function as an explanation of Biden's ideology as it has been mentioned previously that politics and ideology are integrated one another. It is expected that by reading this research, readers can understand that language analysis can be conducted in finding the ideology of a leader, and perhaps, it can give them a visualization of what possible policy or moves that will be taken by the leader in the future.

\section{Critical Discourse Analysis (CDA)}

The development of Critical Discourse Analysis (CDA) is contributed by several theorist such as the ones proposed Fairclough, Van Dijk, George Yule, etc. CDA is the type of analytical 
research on discourse which investigates the way dominance and social power abuse is constructed, recreated, and withstood by text and talk both in the social and political context. Fairclough defines CDA as discourse analysis aiming "to systematically explore often opaque relationships of causality and determination between (a) discursive practices, events and texts, and (b) wider social and cultural structures, relations and processes, is considered an attempt to reveal hidden meanings consciously or unconsciously embedded in an utterance (Wodak \& Kendall, 2007)

\section{Text and Context}

Fairclough (as cited in Jeffries, 2007) texts are considered to be social spaces in which two fundamental processes simultaneously occur. The cognition and representation of the world, as well as social interaction are integrated one another. Context itself is the element that provides the information to answer such questions that is related to the production of a text. In order for a text to be understood, a context is needed for it provides the detail of pragmatic meaning carried by an utterance. Context is defined as the mentally represented structure of the social situation related to the comprehension of a discourse (T. A. Van Dijk, 2008).

\section{Microstructure}

Working with a political discourse means working with the tool that creates what is implied from the text which is called microstructure. We may want to examine texts with propositions that are asserted or presupposed (to be true, to be shared, or to be taken for granted), and hence presented as knowledge (T. A. van Dijk, 2006). Wodak (2009) listed four procedures related to different levels of language, one of which is pragmatic and text-linguistic techniques i.e. analysis of forms of address, speech acts, allusions, presuppositions, conversations, argumentation, rhetoric, quotations, genres, and intertextuality. From this, an understanding can be drawn that presupposed meaning is possible to use in studying political discourse, moreover to obtain the ideology manifested in speeches.

\section{Presupposition}

When an utterance is produced, an assumption is also produced. Yule (1996) stated that speakers assume certain information is already known by their listeners. When a speaker utters something, the utterance comes along with an information that is considered to be a proposition that a speaker wants the listener to understand. There are six types of presupposition proposed by Yule (1996) i.e. existential, lexical, structural, factive, non-factive, and counter-factual.

Existential presupposition is the assumption assumed to be committed to the existence of the entities by the speaker. The noun phrase your house presupposes that you have a car. Lexical presupposition is the use of some forms with their stated meanings interpreted as the presentation of some non-asserted meaning. The sentence The country has been facing more challenging thread presupposes that this mentioned country has faced a situation before it finally escalated to be more challenging currently. Structural presupposition is associated with the use of certain words and phrases. For example, the wh-questions is conventionally interpreted with the presupposition that the information after the wh-form is already known to be the case. Factive presupposition is marked by a piece of information following verbs like know, realize, regret, and phrases like "It's odd that...". Non-factive presupposition is marked by the use of some verbs like dream, imagine, pretend, and allege. Counter-factual presupposition is a conditional forms in subjunctive mood which trigger contrary to fact meaning. 


\section{Ideology}

Dijk (1997) stated that discourse in this approach essentially serves as the medium by which ideologies are persuasively communicated in society, and there by helps reproduce power and dominant of specific group or classes. In general understanding, ideology is a belief that is considered to be true and hold by some groups. Ideology needs to be socially inherent, thus, it cannot be personal or individual. An ideology needs to be shared between the group members. Political speeches are proven to be one of the most effective vessel to share an ideology. It has been done since the dawn of men and is still being practiced until now.

\section{METHOD}

This is a descriptive qualitative research which is described as a research which explores questions such as what, why, and how, rather than how many and how much. It is primarily concerned with meaning rather than measuring (Keegan, 2009). There are some stages conducted in this research i.e. collecting the transcription of Biden's inaugural speech from The White House official website, analyzing the content of the speech in which types of presupposition are later classified, extracting the ideology by investigating the meaning obtained from the analysis of presupposition, and presenting the face of Biden's ideology.

\section{RESULTS AND DISCUSSION}

\section{Results}

After analyzing the text of Biden's inaugural speech, the writer found three types of presupposition i.e. lexical, existential, and factive. The findings can be seen as follows:

Table 1. Types of Presupposition Occur in Biden's Speech

\begin{tabular}{llll}
\hline NO & TYPES OF PRESUPPOSITION & FREQUENCY & PERCENTAGE \\
\hline 1 & Lexical & 17 & $50 \%$ \\
2 & Existential & 13 & $38,23 \%$ \\
3 & Factive & 4 & $11,76 \%$ \\
4 & Structural & - & $0 \%$ \\
5 & Non-Factive & - & $0 \%$ \\
6 & Counter-Factual & - & $0 \%$ \\
& & 34 & $100 \%$ \\
\hline
\end{tabular}

\section{Lexical Presupposition}

1. Few periods in our nation's history have been more challenging or difficult than the one we're in now.

(>> The period is now challenging, but America ever faced even more challenging situation in the past)

2. Through a crucible for the ages America has been tested anew and America has risen to the challenge.

(> America is used to face challenge)

3. We will press forward with speed and urgency, for we have much to do in this winter of peril and possibility. Much to repair. Much to restore. Much to heal. Much to build. And much to gain. 
(>> Many things in this country are broken, gone, sick, and destroyed, thus they need to be repaired, restored, healed, built, and gained)

4. To overcome these challenges - to restore the soul and to secure the future of America - requires more than words. It requires that most elusive of things in a democracy: Unity. Unity.

(>> Problems are occurring and to fix this, they need something that is missing nowadays: unity)

5. We can right wrongs. We can put people to work in good jobs. We can teach our children in safe schools. We can overcome this deadly virus. We can reward work, rebuild the middle class, and make health care secure for all. We can deliver racial justice.

(>> Things are getting wrong there. Many jobs are lost, schools are not safe, deadly virus is uncontrollable, people works are unrewarded, middle class is getting poorer, health care is not secured, and racial justice is not available)

6. Today, we celebrate the triumph not of a candidate, but of a cause, the cause of democracy.

(〉> His winning in election is the prove of democracy)

\section{Existential Presupposition}

1. I ask every American to join me in this cause. Uniting to fight the common foes we face: Anger, resentment, hatred. Extremism, lawlessness, violence. Disease, joblessness, hopelessness.

(>> There is anger, resentment, hatred, extremism, lawlessness, violence, disease, joblessness, and hopelessness in the U.S.)

2. Every disagreement doesn't have to be a cause for total war.

(>> There is disagreement happening in the U.S. and it caused total war)

3. Here we stand, where 108 years ago at another inaugural, thousands of protestors tried to block brave women from marching for the right to vote.

(> A protest occurred 108 years ago trying to block black women to vote)

4. Today, we mark the swearing-in of the first woman in American history elected to national office - Vice President Kamala Harris.

(> The first woman in American history became vice president)

5. We must end this uncivil war that pits red against blue, rural versus urban, conservative versus liberal.

( $\gg$ There is uncivil war between contradicting parties)

6. A cry for survival comes from the planet itself. A cry that can't be any more desperate or anymore clear.

(>> The issue of environment does exist)

\section{Factive Presupposition}

1. What are the common objects we love that define us as Americans? I think I know. Opportunity. Security. Liberty. Dignity. Respect. Honor.

(>> The common objects that define the Americans)

2. It's taken as many lives in one year as America lost in all of World War II.

( > America lost in World War II)

\section{Discussion}

This part contains the interpretation of findings in the data. From the data analysis, the researcher found three types of presupposition in the speech delivered by Joe Biden in his 
inauguration. Among the three, lexical presupposition appeared to be the most frequent one. If we put deeper attention on the content of the speech, it is seen that Biden tried to address an invitation the U.S. citizen to be more considerate towards the issues exist in this country. Biden stated in his speech that the U.S. is now facing many problem commencing from economic, social and politics, health, to environment. The appearance of lexical presupposition confirms that the use of some forms with their stated meanings is interpreted as the presentation of some non-asserted meanings.

Biden's speech mostly contains his concern on problems faced in the U.S. and he asked his people to unite and believe that these problems can be solved if they are united as a nation. In terms of ideology, it is obvious that Biden is a democrat. As he repeatedly stated the word democracy in the beginning of his speech. He mentioned that healthcare insecurity is indeed becomes major issue. Related to this, as it is known, Trump's policy on healthcare failed to mitigate Covid-19 pandemic problems. He also promised to repeal Obamacare. From his speech, we can forecast what move that will be chosen by Biden in handling healthcare issue. He also stated that the cause of his victory in the election is democracy. He holds this belief that unity is the key for the country to keep moving forward. He did not deny that America is in big trouble. He admitted the fact that extremism, white supremacy, racial inequality, and joblessness are among the problems being faced right now. Speaking of racial justice, it can also be concluded that Biden's ideology is totally in the opposite direction from Trump's. Biden believes that racial justice is for everyone. From his statement, it can be predicted that Biden will soon try to redirect the policy in Trump's administration such immigrants' issue. The term Islamic terrorism did not appear in his speech. This shows that Biden is not an Anti-Muslim like his predecessor. The last ideology that can be seen from his speech deals with environment issue. He mentioned that the planet is crying for survival. To this extent, Biden showed his standing towards the issue of climate change.

\section{CONCLUSION}

Based on the analysis of the data, it is found that there are three types of presupposition in Joe Biden's speech i.e. lexical, existential, and factive. Lexical presupposition appeared to be the most frequent one in the data. The frequent appearance of lexical presupposition is in fact related to the contents in Biden's speech which mostly intend to unite the country together again so that they can face the problems occurring lately. In terms of ideology, it can be concluded that Biden is a true democrat, oppose racial injustice, in favor of immigrants, and concerns toward climate change. Biden's ideology manifested in his speech is possible to be identified by the application of presupposition analysis in his inaugural speech.

\section{ACKNOWLEDGMENTS}

The idea of this research is derived from none other than the admiration of the researcher towards language and its ability to construct meaning. The researcher would like to thank Politeknik Caltex Riau for its support in triggering its staff to conduct a research based on each discipline.

\section{REFERENCES}

Bayram, F. (2010). Ideology and Political Discourse: a Critical Discourse Analysis of Erdogan'S Political Speech. Arecls, 7(January 2009), 23-24. http://research.ncl.ac.uk/ARECLS/volume7/bayram_vol7.pdf 
Fairclough, N. (2020). Language and power 2000. In Language and Power. Longman Group Ltd. https://doi.org/10.4324/9781315838250-15

Jeffries, L. (2007). Textual Construction of the Female Body: A Critical Discourse Approach. Palgrave Macmillan.

Keegan, S. (2009). Qualitative research: Good decision making through understanding people, cultures and markets. Kogan Page Publishers.

Puspasari, A. (2014). Presuppositions in the slogans of Indonesian Universities. Jurnal Bina Bahasa, 7(1), 1-16.

Van Dijk, T. (1997). Discourse as interaction in society. In T. Van Dijk (Ed.), Discourse as social interaction (Vol. 2, pp. 1-37). SAGE Publications Ltd.

van Dijk, T. A. (2006). Ideology and discourse analysis. Journal of Political Ideologies, 11(2), 115-140. https://doi.org/10.1080/13569310600687908

Van Dijk, T. A. (2006). Discourse and manipulation. Discourse and Society, 17(3), 359-383. https://doi.org/10.1177/0957926506060250

Van Dijk, T. A. (2008). Discourse and Power. Palgrave Macmillan.

Wodak, R. (2009). The discourse of politics in action: Politics as usual. In The Discourse of Politics in Action: Politics as Usual. Palgrave Macmillan. https://doi.org/10.1057/9780230316539

Wodak, R., \& Kendall, G. (2007). What is critical discourse analysis? Forum Qualitative Sozialforschung, 8(2), 9-34. https://doi.org/10.7203/qfilologia.11.5041

Yule, G. (1996). Pragmatics. Oxford University Press. 